Article

\title{
Corrosion and Conservation Management of the Submarine HMAS AE2 (1915) in the Sea of Marmara, Turkey
}

\author{
Ian D. MacLeod \\ Western Australian Maritime Museum, Victoria Quay Drive, Fremantle, WA 6160, Australia; \\ ian.macleod@museum.wa.gov.au
}

Received: 12 February 2019; Accepted: 5 March 2019; Published: 14 March 2019

\begin{abstract}
The wreck site of the Australian First World War submarine HMAS AE2 in the Sea of Marmara had a salinity of $26 \%$ (parts per thousand) for the first $13 \mathrm{~m}$, which increased to $41 \%$ at $21 \mathrm{~m}$, after which it remained constant to the bottom at $72 \mathrm{~m}$, where the dissolved oxygen was three parts per million. The vessel is protected by a very dense anaerobic concretion and lies half above a silt mound. Cross-sections of a concretion sample revealed the original surface, associated paint films and a series of burial-exposure episodes that reflected periodic changes in the silt levels, which are likely associated with major storms. Core samples of sediment have established the impact of the vessel on the site. Corrosion simulation experiments have established the direct linkage between chloride levels underneath the concretion layer and the $\mathrm{pH}$ of the entrapped solution. Following the initial drop camera survey, an ROV (Remote Observation Vehicle) examination of the interior of the boat showed a remarkable degree of preservation. A network of ten-tonnes of zinc anodes were distributed at the stern, amidships and the bow to bring about in-situ conservation of the historic submarine.
\end{abstract}

Keywords: AE2 submarine; Turkey; First World War; in-situ conservation; sediment cores; corrosion; simulation; sacrificial anodes

\section{Introduction}

The Australian submarine AE2 was built in 1912 by Vickers Armstrong at Barrow-in-Furness, England, launched in 1913 and it arrived in Australia on 24th May in 1914 under the command of Lieutenant Commander Henry Stoker. The AE2 was on patrol in New Guinea when her sister ship AE1 was lost, including all hands. The latter wreck was discovered in December 2017 at a depth greater than $300 \mathrm{~m}$. the Duke of York Islands in Papua New Guinea. The vessel had imploded when it exceeded its crush depth. The AE2 returned to Australia and escorted the second ANZAC convoy to the island of Tenedos in the Aegean Sea. After penetrating the heavily mined Dardanelles, AE2 successfully reached the Sea of Marmara on the 25 April 1915, providing a boost for the ANZAC Gallipoli Campaign. The submarine created havoc for five days, before it was holed by the Turkish torpedo boat Sultanhisar when it broached after mechanical problems. Stoker ordered his crew to abandon ship and then scuttled the vessel, which now lies in $73 \mathrm{~m}$. of water on a silt mound at the bottom of the Sea of Marmara at position $47^{\circ} 32^{\prime}$ N, $27^{\circ} 17^{\prime}$ E. The wreck site was discovered by Selçuk Kolay, Director of the Rami Koçh museum in Istanbul in 1995, and the identity confirmed by a combined Turkish and Australian team in 1998. Owing to its cultural significance to both Turkey and Australia, the 55-m long submarine was considered for possible relocation to a dry dock, where it could be conserved at a purpose-built museum. Alternative options included moving it to depths of 20-25 m, where normal scuba supply diving would enable full maritime archaeological inspection, documentation and in-situ 
conservation. At a similar time, maritime archaeological investigations, at the Dardanelles battlefields, by the Australian team, led by Tim Smith, found significant numbers of sunk barges and support vessels in remarkably good condition [1]. Previous experience with in-situ conservation of historic iron artefacts has demonstrated that the monitoring and treatment of anchors, cannon and the Xantho engine was practical, so long as the sites were accessible by scuba [2,3]. Since the submarine lies in deep water, all diving involves use of mixed gases (helium, oxygen and nitrogen), and this necessitates two hours of decompression bottom time for each 30-min dive. An additional complication is the presence of one unexploded torpedo in the stern of the boat. Both the explosive charge and the mercury fulminate detonator become increasingly sensitive to shock over time, so the vibrations associated with a relocation were likely to result in a devastating detonation. Until the interior of the submarine could be analysed for any traces of high explosives, which would indicate the warhead is wet and; therefore, safe, it had to be regarded as being very sensitive to shock and vibrations. Thus, in 2014, a more detailed examination took place, which involved opening the main hatch to allow a remote observation vehicle (ROV) inside the boat to assist in the development of future management plans, which included in-situ treatment. During this trip the anodes were attached to the submarine.

\section{Materials and Methods}

During the 2004 assessment the water column above the wreck was measured for salinity, dissolved oxygen (YSI probe) and temperature at 0.5-m intervals, using a TPS 90DC. Measurements on the profiles from the sediment cores collected data on the dissolved oxygen, $\mathrm{pH}$ and redox potentials, using $0.3 \mathrm{~mm}$ diameter rhodium wire. The microelectrodes were inserted through pre-drilled $3 \mathrm{~mm}$ diameter holes in the polycarbonate core holders, and the measurements were made with a Unisense Microsensor Multimeter. This instrument has amperometric channels for measurement of dissolved oxygen and one for potentiometric measurements of redox potentials and $\mathrm{pH}$, and direct communication to PC via a USB connection. The holes were sealed with PVC tape until measurement access was required. The hand-held readings from the Cygnus ${ }^{\circledR}$ ultrasonic metal thickness gauge had an accuracy of $\pm 0.1 \mathrm{~mm}$ of metal. In-situ $\mathrm{pH}$ measurements on the submarine were made from a 100-m-rated polycarbonate box with a BDH (British Drug House) Gelplas flat surface (pressure compensating) electrode connected to a Cyberscan $200 \mathrm{pH}$ metre. The voltage was measured using a Fluke digital multimeter with the positive connection to a platinum electrode $(2 \mathrm{~mm}$ outside diameter) encased in non-conducting epoxy resin, and the negative terminal connected to a flow-through $\mathrm{Ag} / \mathrm{AgCl}$ electrode, which was calibrated in the field station against a known standard reference electrode. All electrode wires leading into the metre box had double " $\mathrm{O}$ " rings to guard against possible leakage under pressure at $70+\mathrm{m}[4,5]$. The surface $\mathrm{pH}$ was measured after drilling through rock-hard anaerobic concretion with a masonry-tipped drill bit.

\section{Results}

\subsection{Physical Oceanography of the Wreck Site in the Sea of Marmara}

During the 2004 assessment, the water column above the wreck was measured for salinity, dissolved oxygen (YSI probe) and temperature at 0.5-m intervals, using a TPS 90DC meter that logged the data, to a maximum depth of $73 \mathrm{~m}$. The first $13 \mathrm{~m}$ had a mean salinity of $26.1 \% 0 \pm 0.1 \%$, which reflects evaporative concentration of the $18 \%$ water inflowing from the Black Sea. Over the next eight metres, the salinity rapidly increased to $41.3 \% \pm 0.8 \%$ at the bottom of the halocline. The higher salinity is typical of the hypersaline Aegean Sea, which enters the Sea of Marmara via the Dardanelles. Captain Stoker had used this counter current to help him penetrate the mined straits. At the 2004 halocline there was a corresponding thermocline (change in temperature) where the temperature fell from 26 to $18{ }^{\circ} \mathrm{C}$ and a second thermocline, at $40 \mathrm{~m}$, saw the temperature fall from 18 to $16^{\circ} \mathrm{C}$, which was due to the heat capacity of the higher salinity water (Figure 1). 


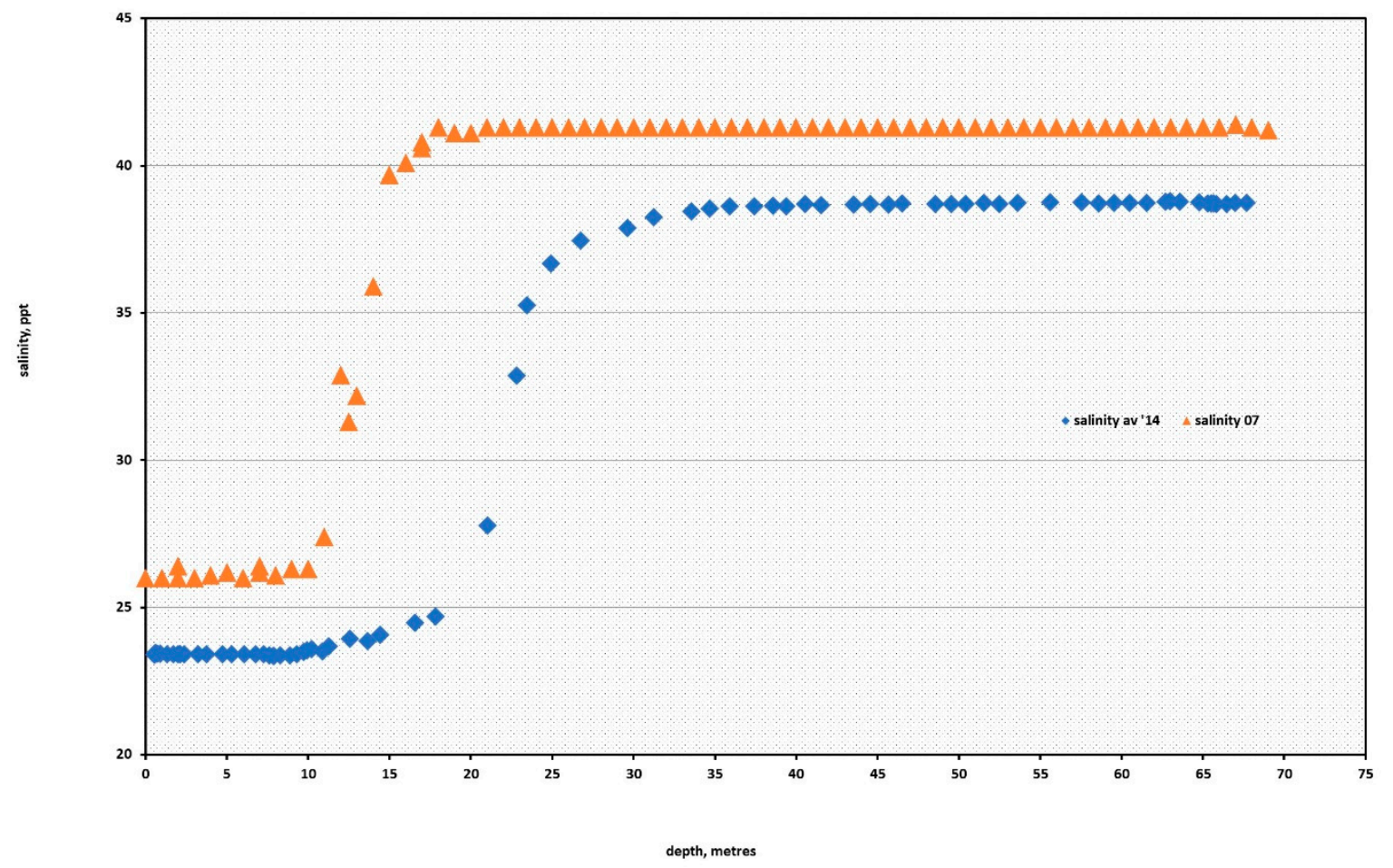

Figure 1. Salinity on the AE2 site in September 2007 (orange triangles) and June 2014 (blue diamonds).

During the 2014 expedition, a more sophisticated Sonde recorded the dissolved oxygen, temperature, salinity and redox potential every $20 \mathrm{~s}$. Graphical comparative analysis of the data from the two times of the summer and spring, seven years apart, showed similar trends. This data recorded the greatest fall in temperature in the lower end of the less salty water, between 10-20 m, and above this depth the temperature was relatively constant at $15 \pm 0.9^{\circ} \mathrm{C}$ between 20 and $72 \mathrm{~m}$, the depth of the wreck.

The surface waters in the Sea of Marmara were well oxygenated between 7 and $5.5 \mathrm{ppm}$, as shown in the 2007 and 2014 profiles shown in Figure 2. The data from 2007 shows the dissolved oxygen falling from 5 to $3 \mathrm{ppm}$ as the depth increases from 35 to $50 \mathrm{~m}$. At the upper sections of the submarine, the dissolved oxygen was recorded at $2.8 \pm 0.2 \mathrm{ppm}$, which represents $36 \%$ saturation of the seawater for a salinity of $41.3 \%$ at $16{ }^{\circ} \mathrm{C}$ [6].

The data from June 2014 showed a dissolved oxygen that fell with increasing salinity, to reach a minimum of $4.5 \mathrm{ppm}$, and then increased in response to currents flowing in the hypersaline waters at depths until the submarine environment was reached, at $67 \mathrm{~m}$, where it fell to the 3-ppm level seen in 2007. 


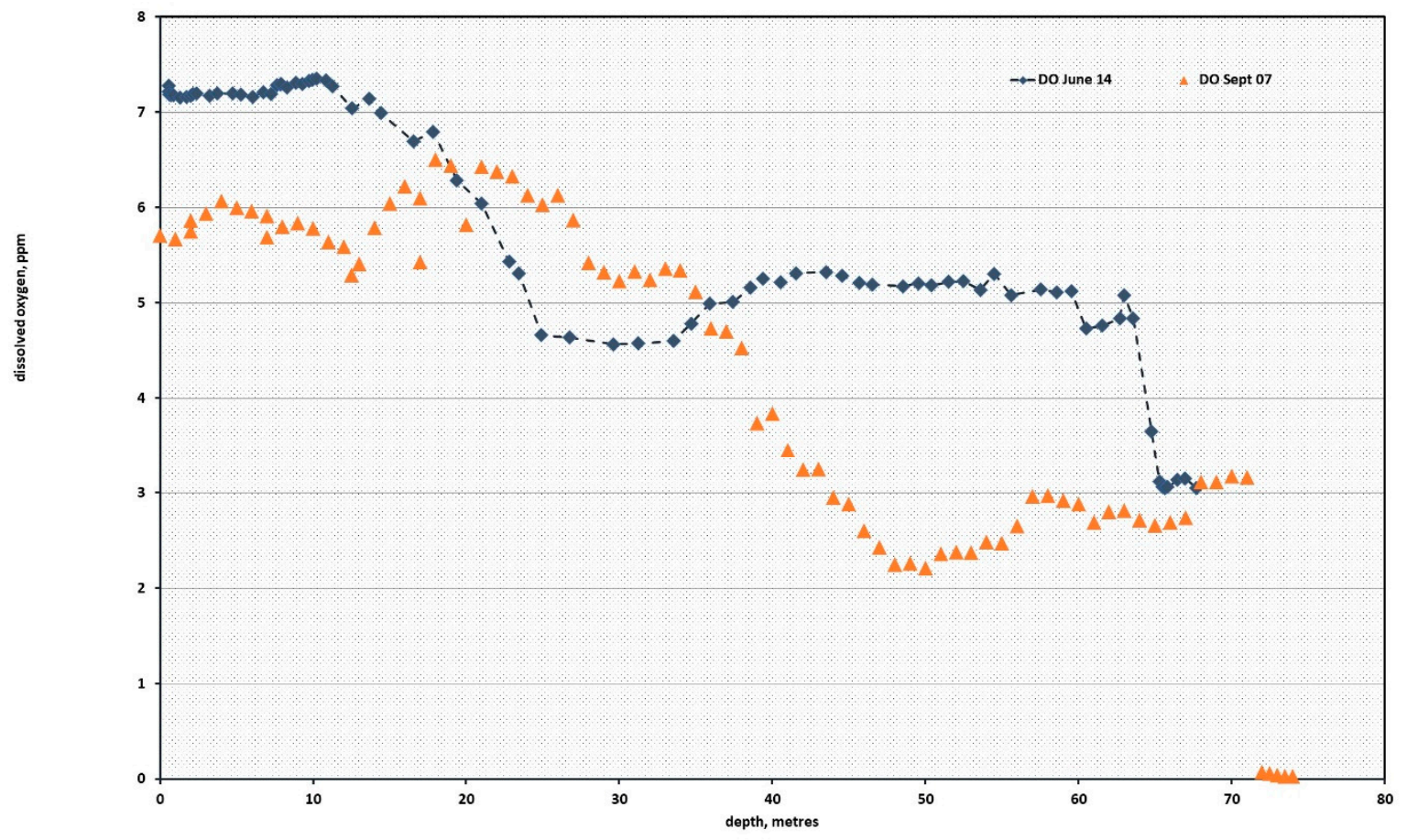

Figure 2. Dissolved oxygen vs. depth for the AE2 site; the zero-ppm data in 2007 (orange triangles) is when the weighted probe penetrated the silt mound. June 2014 data blue diamond shapes.

\subsection{Corrosion of the Submarine in the Sea of Marmara}

The submarine lies on the bottom of the Sea of Marmara with a silt mound coming half-way up the hull. Images of the wreck at www.submarineinstitute.com show that a combination of corrosion and trawler net damage has holed the thin plate sections at the bow and on the combing (structure that covers a range of fittings to streamline the water flow) behind the conning tower, leaving the structural frames exposed (Figures 3 and 4). The drop camera used in 2007 showed that the non-ferrous metal fixtures on the interior of the conning tower were covered in a thin layer of concretion from the galvanic protection afforded by the surrounding iron objects [7]. The interior of the conning tower was made of bronze to make sure that the magnetic compass would not be affected by the proximity of ferrous metals. The hatch cover, ladder, control valves and steering gear were all made of brass or bronze. Owing to the confined nature of the seawater inside the vessel it is likely that the massive banks of batteries will be involved in long-range or proximity corrosion that will have affected the electric motors and the diesel engines used for recharging the battery banks [8].

Proximity corrosion refers to long-distance galvanic coupling found on historic shipwreck sites and on submerged off-shore modern structures, such as production gas and oil platforms. When dissimilar metals are covered with a concretion layer, they lose their electrical isolation, and the more reactive metals corrode while the more noble alloys are protected.

Based on the drop camera study, it was deemed likely that the hatch cover could be opened, since cathodic protection from the hull will have prevented major corrosion attack on the hinge mechanism. The opening of the main hatch to allow the ROV to enter the submarine was delayed underwater when divers found that there was 25-35-mm-thick concretion on the hatch mechanism, some 15 times thicker than expected. Because the higher salinity environments have higher total mineral content, the alkalization of the hinge resulted in a massive concretion deposit (Figure 5). The bond around the spindle and hinge brackets was broken using a combination of de-concreting tools and a hydraulic jack. A chain block was needed to gently ease the hatch open for the first time in over 100 years. Cathodic current from reduction of oxygen on the non-ferrous metals makes the surface more alkaline (Equation (1)). In the case of the $A E 2$ the outcome was the precipitation of massive calcareous deposits. 


$$
\mathrm{O}_{2}+2 \mathrm{H}_{2} \mathrm{O}+4 \mathrm{e}^{-} \rightarrow 4 \mathrm{OH}^{-}
$$

By consuming the soluble bicarbonate ion present in seawater, the hydroxide ions produced in Equation (1) increase the carbonate concentration and so the calcareous deposits are formed (Equation (2)).

$$
\mathrm{Ca}^{2+}+\mathrm{HCO}_{3}{ }^{-}+\mathrm{OH}^{-} \rightarrow \mathrm{CaCO}_{3} \downarrow+\mathrm{H}_{2} \mathrm{O}
$$

A barnacle from the base of the concretion was a deep charcoal grey to black, which is likely to be associated with magnetite, the corrosion product associated with iron corrosion in a low oxygen environment.

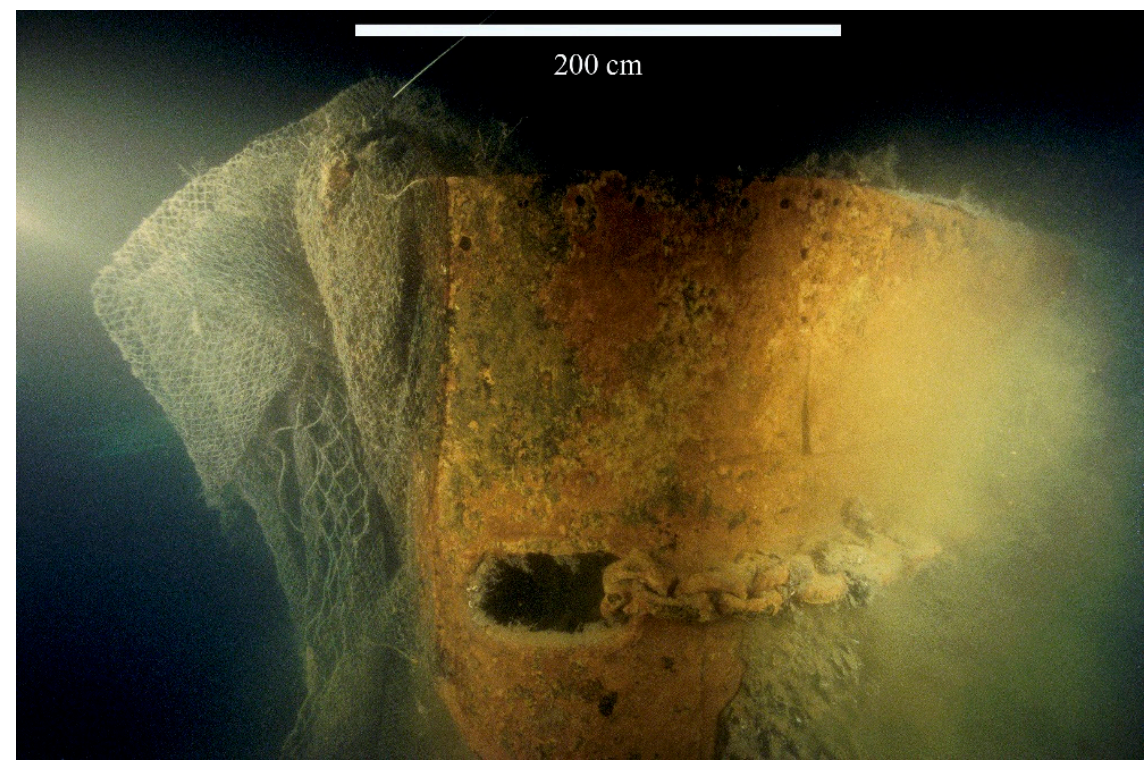

Figure 3. Trawler net damage on the AE2 submarine.

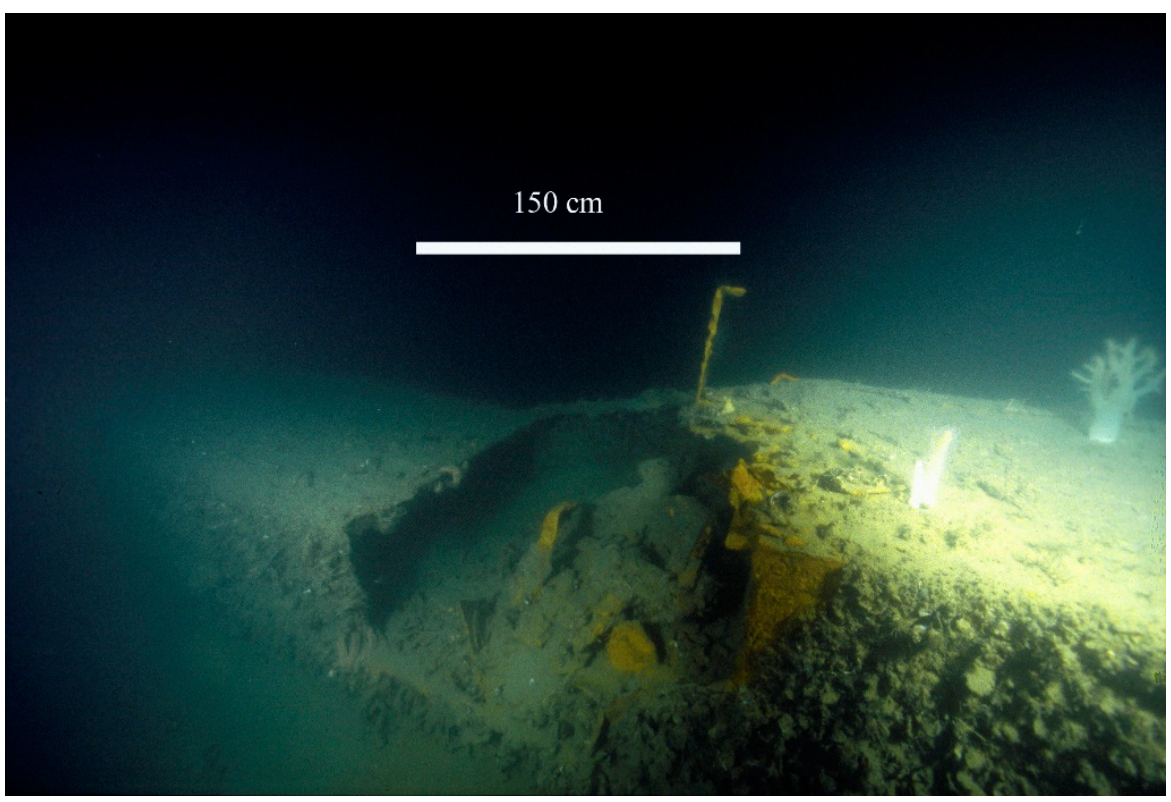

Figure 4. Corrosion damage to the casing of the AE2; yellow shows active corrosion. 


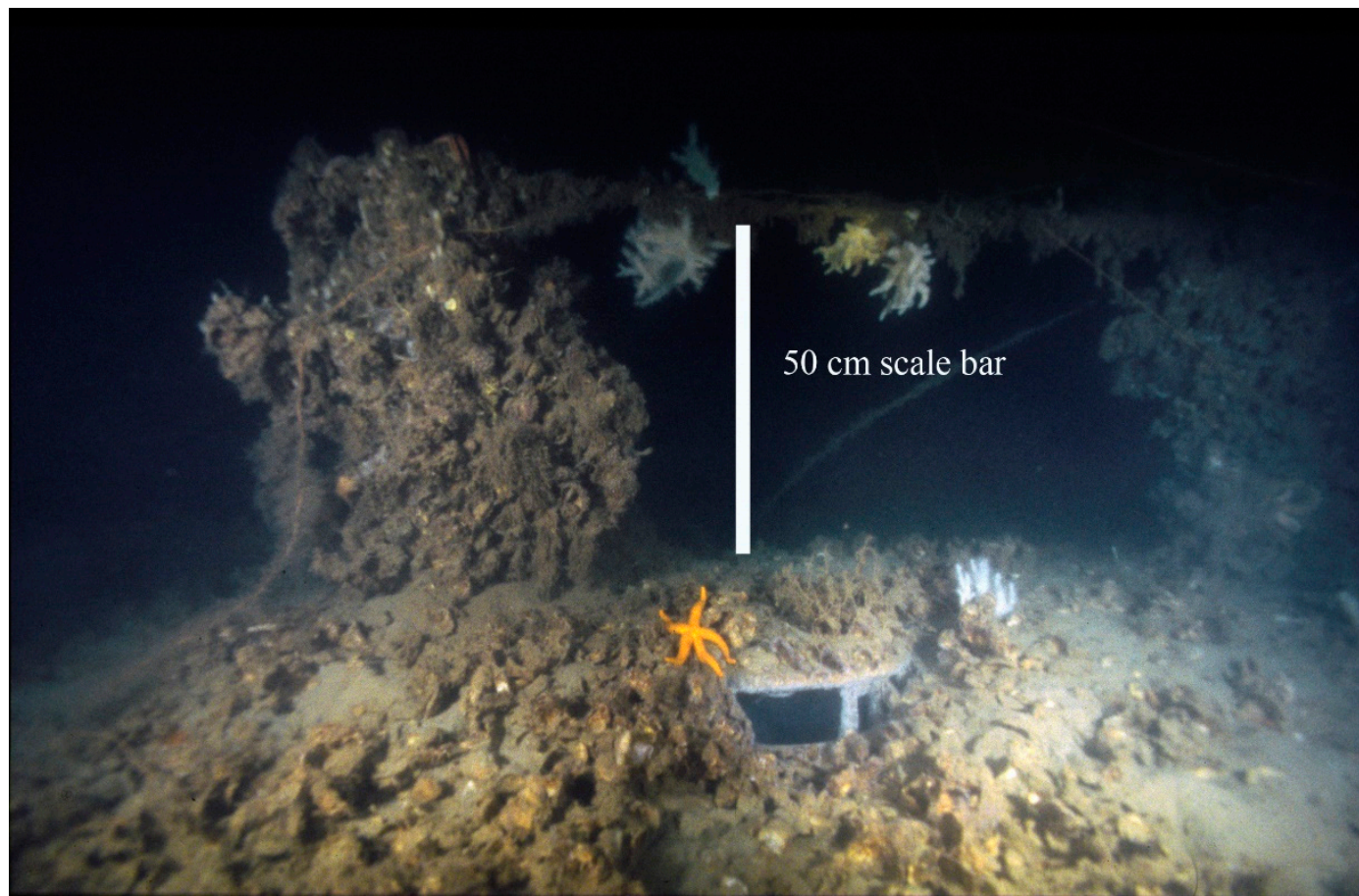

Figure 5. Concreted main hatch way showing the $10 \mathrm{~cm}$ gap for insertion of the drop camera and the very thick marine concretion deposits.

\subsection{In-situ Corrosion Assessment}

Operational constraints limited data collection in 2007 to one location. The measurements were made $\approx 6 \mathrm{~m}$ aft of the leading edge of the casing, behind the conning tower. The corrosion potential $\left(\mathrm{E}_{\text {corr }}\right)$ value was -0.619 volts vs. $\mathrm{Ag} / \mathrm{AgCl}_{\text {sea, }}$, which had a calibrated voltage of +0.228 volts vs. the Standard Hydrogen Electrode (SHE). Comparison with another historic shipwreck at the same depth showed that the $A E 2$ corrosion potential was the same as those found on the turret and armour plating sections of the USS Monitor (1862), which had a mean value of $-0.600 \pm 0.016$ volts vs. $\mathrm{Ag} / \mathrm{AgCl}$ [9]. The $\mathrm{pH}$ was 7.27 , which is the same as the mean $\mathrm{pH}$ of $7.11 \pm 0.54$ for the WWI "J5" submarine in Bass Strait, Victoria, Australia.

\subsection{Concretion and Site History}

The accidental impact of a two-tonne concrete anchor during an intense storm removed a small section $\left(50 \mathrm{~cm}^{2}\right)$ of concretion from the $A E 2$ hull, which facilitated direct measurement of the hull plate thickness. Samples of the concretion were examined by materials and corrosion scientists. An ROV inspection showed that the bare metal had been covered by a new concretion layer within three years $[10,11]$. The concretion sample showed a typical anaerobic concretion, with a very dense milieu of sharp shell debris and black iron corrosion products, which consisted of magnetite $\left(\mathrm{Fe}_{3} \mathrm{O}_{4}\right.$ determined by petrographic analysis) and a number of iron sulphides, which included FeS, based on atomic ratios from the Energy Dispersive X-Ray Spectrum (EDS) analysis from the electron microscope. As expected, there were several other species, containing iron, sulphur, chloride and oxygen, present [12]. Samples of the priming coat of red lead oxide, $\mathrm{Pb}_{3} \mathrm{O}_{4}$, were found at the original metal surface, which was covered by a primary concretion layer $\approx 1.6 \mathrm{~mm}$ thick, a secondary $8.8 \mathrm{~mm}$ layer, and the outer layer was $3.9 \mathrm{~mm}$ thick. Sections of concretion showed pitting corrosion beneath the original surface, to a depth of $3 \mathrm{~mm}$.

The differences in colonization of the conning tower and the upper sections of the combing indicates that the sediment levels have not always been the same as those found when the site was inspected in 2007. The concretion model indicates an initial four-five years of relatively intense 
corrosion, as paint layers are penetrated and a steady corrosion rate is established [13]. The primary corrosion layer in the concretion appears to correspond to the first $13 \pm$ two years of immersion (i.e., from 1915 to 1928). Changing conditions due to massive storms disturbing the site resulted in the second and third layers.

Samples of oil from inside the boat were collected from the surface of the ROV following its successful navigation of the internal spaces of the engine room. Viscosity data and gas chromatographic analysis of the volatile organic compounds coming from the oily residue indicated that it was diesel fuel, which had been leaking from the forward tanks. The analysis showed that the oil was biologically fractionated through removal of the sour and acidic smelling thiols and thiophenes. The bacteria preferentially consumed much of the long chain alkanes of the general formula $\mathrm{C}_{n} \mathrm{H}_{2 n+2}$ (Figure 6). The biodegradation of the AE2 oil mixture was indicated by the presence of the branched alkanes, norpristane $\left(\mathrm{C}_{18} \mathrm{H}_{38}\right)$, pristane $\left(\mathrm{C}_{19} \mathrm{H}_{40}\right)$ and phytane $\left(\mathrm{C}_{20} \mathrm{H}_{42}\right)$, which are much more stable than the branched hydrocarbons. It is interesting that pristane is derived from shark liver oil and so this may be one of the principal components of lubricating oils and diesel fuel for the generators that was recovered from the surface of the ROV. The video inside the submarine has evidenced movement of large black mats of biological growth, which are the by-products of the microbiological attack on the diesel fuel.

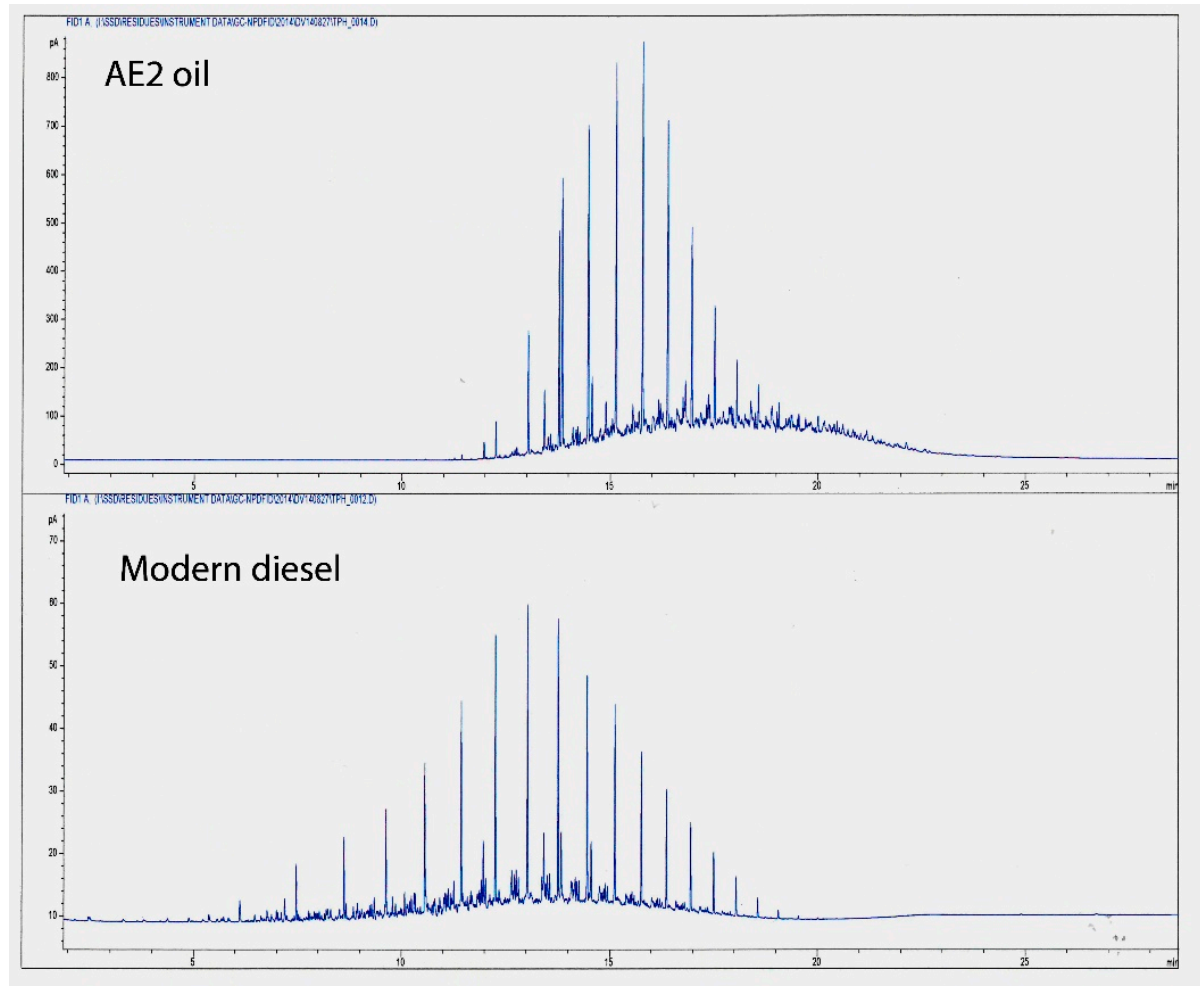

Figure 6. Gas chromatographs of AE2 oils compared with undegraded diesel fuel.

\subsection{Assessment of the Corrosion Rate on AE2}

The hand-held readings from the Cygnus ${ }^{\circledR}$ ultrasonic metal thickness gauge gave $4.6 \pm 0.9 \mathrm{~mm}$ for the bare metal of the ballast tank, which was originally $6.35 \mathrm{~mm}$ thick. The apparent loss of $1.55 \mathrm{~mm}$ of metal over the 92.4 years of immersion equates to a corrosion rate equivalent to $0.017 \pm 0.003 \mathrm{~mm} /$ year. Comparative data from the Monitor showed that the interior of the turret, which was in an anaerobic microenvironment like the $A E 2$, had the same corrosion rate of $0.016 \mathrm{~mm} /$ year [14]. It should be recalled that the $\mathrm{E}_{\text {corr }}$ values of the two wrecks were the same. The corrosion rate for iron shipwrecks in open-ocean waters can be calculated using an empirical equation (Equation (3)) relating the log of 
the corrosion rate, measured in $\mathrm{mm} /$ year as $d_{g}$ or depth of graphitization of cast iron objects on the wreck to water depth $d$ in metres [3] viz.,

$$
\text { Open-ocean } \log d_{g}=-0.630-0.0156
$$

With a depth of $71 \mathrm{~m}$, Equation (3) predicts a corrosion rate of 0.018(3) $\mathrm{mm} /$ year, which is the same as the observed rate of $0.017 \pm 0.003 \mathrm{~mm} /$ year. The silty microenvironment of the submarine would naturally result in an overall lower corrosion rate than that for wrecks lying proud of the seabed in well oxygenated conditions. More simply, the lower sections of the submarine may be in a better state of preservation, but testing would be required to assess the impact of microbially-induced corrosion (MIC) in the lower section of the pressure hull.

\subsection{Sediment Cores}

\subsubsection{Redox Potentials}

A fundamental archaeological principal is to establish what impact a given deposit has on its immediate microenvironment and vice versa. Thus, core samples were recovered in the immediate vicinity of and at $20 \mathrm{~m}$ distance from $A E 2$. The cores were chemically characterized through measurements of the dissolved oxygen, $\mathrm{pH}$ and redox potentials. The mean redox potential of the sediment core adjacent to the vessel was $+0.119 \pm 0.044$ volts vs. NHE (Normal Hydrogen Electrode), which was statistically indistinguishable from the off-site core, $+0.157 \pm 0.038$ volts (Figure 7).

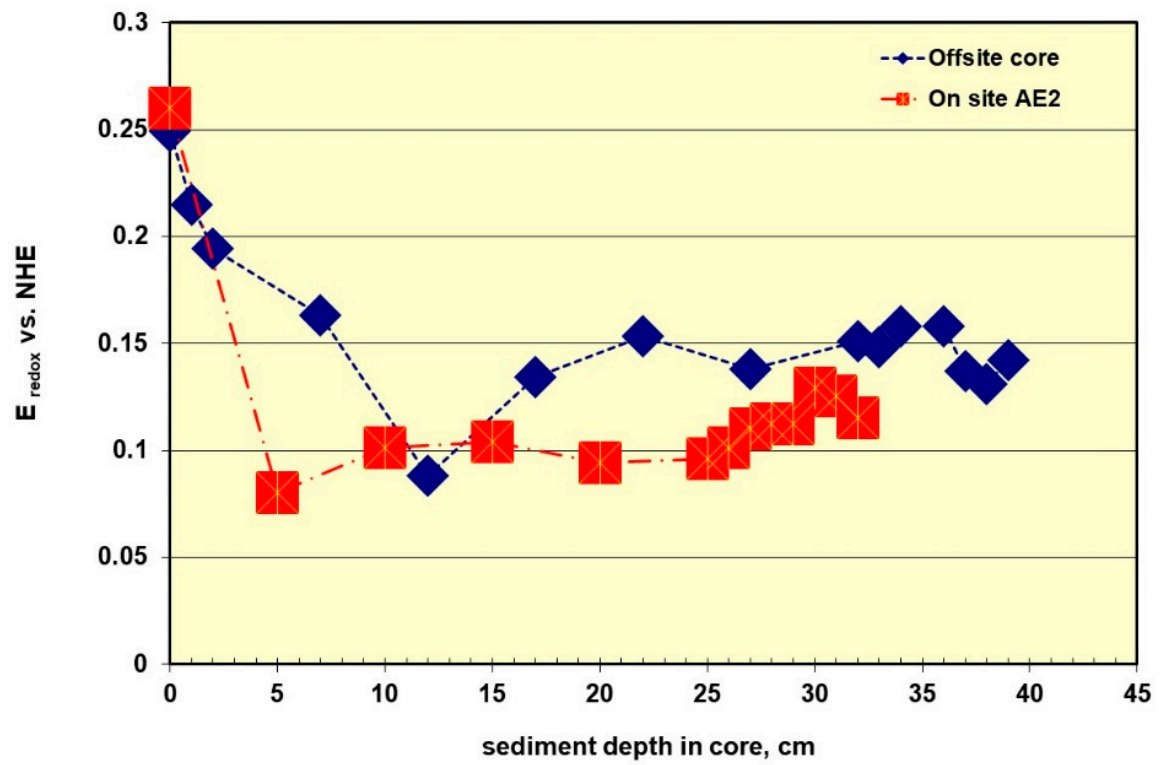

Figure 7. Voltage $\mathrm{E}_{\mathrm{h}}$ readings on the two cores relative to the Normal Hydrogen Electrode.

The ${ }^{A E 2} \mathrm{E}_{\mathrm{h}}$ fell by $180 \mathrm{mV}$, from 0.260 , in the first five $\mathrm{cm}$ of sediment, while the off-site sample took $30 \mathrm{~cm}$ to fall to the same minimum value of $0.082 \pm 0.003$ volts. The more rapid fall in the redox potential for the $A E 2$ core indicates that the microenvironment near the submarine rapidly becomes anaerobic as a direct result of the corrosion process consuming oxygen trapped in the silt. This is supported by the observation that as the core depth increased the $A E 2$ core remained relatively constant at $0.107 \pm 0.014$ volts, while the off-site redox potential had a mean value of $0.142 \pm 0.020$ or some $35 \mathrm{mV}$ more oxidizing than that by the submarine (Figure 7). This indicates that the distance of the impact of the submarine on the microenvironment is less than $20 \mathrm{~m}$. 


\subsection{2. $\mathrm{pH}$ Profiles}

Analysis of the redox and the $\mathrm{pH}$ data of the $A E 2$ core indicated that the reduction of dissolved oxygen present in the sediment was the dominant electrochemical process viz,

$$
\frac{1}{2} \mathrm{O}_{2}+2 \mathrm{H}^{+}+2 \mathrm{e}^{-} \rightarrow \mathrm{H}_{2} \mathrm{O}
$$

The regression analysis of the $\mathrm{E}_{\mathrm{h}}$ and $\mathrm{pH}$ data conformed to the equation $\mathrm{E}_{\mathrm{h}}=0.759-0.084 \mathrm{pH}$ vs. NHE which had an $R^{2}$ of 0.909 . The intercept value of $0.759 \pm 0.069$ volts is the same as the standard reduction potential of 0.680 volts for the above oxygen reduction reaction; however, the slope for the $\mathrm{pH}$ at $0.084 \pm 0.009$ volts is higher than the theoretical 0.059 volts. It is likely that the high salinity of the Sea of Marmara resulted in the non-ideal behaviour of the electrolytes, which were based on behaviour at infinite dilution. The off-site core data did not follow any systematic trend.

The ${ }^{A E 2} \mathrm{pH}_{\text {core }}$ values showed a steady alkaline microenvironment for the initial $25 \mathrm{~cm}$ at $\mathrm{pH}$ $7.80 \pm 0.02$, before rapidly falling over the last $7 \mathrm{~cm}$ at a rate of $-0.05 \mathrm{pH} / \mathrm{cm}$ distance down the core (Figure 8). The change in ${ }^{A E 2} \mathrm{pH}_{\text {core }}$ may reflect a limiting impact of the vessel on the sediment, since the $\mathrm{pH}$ values for both cores coincided at $7.3 \pm 0.1$ after a core depth of $\approx 30 \mathrm{~cm}$ of sediment. The off-site $\mathrm{pH}_{\text {core }}$ rapidly fell from its initial value of 7.7 to $7.1 \pm 0.1$ in the first $25 \mathrm{~cm}$ of sediment. The dissolved oxygen measurements in the $A E 2$ core recorded seven zero values, with a mean of $0.018 \pm 0.023 \mathrm{ppm}$ (i.e., essentially zero), while the off-site core mean was $0.067 \pm 0.068 \mathrm{ppm}$ with five zero values.

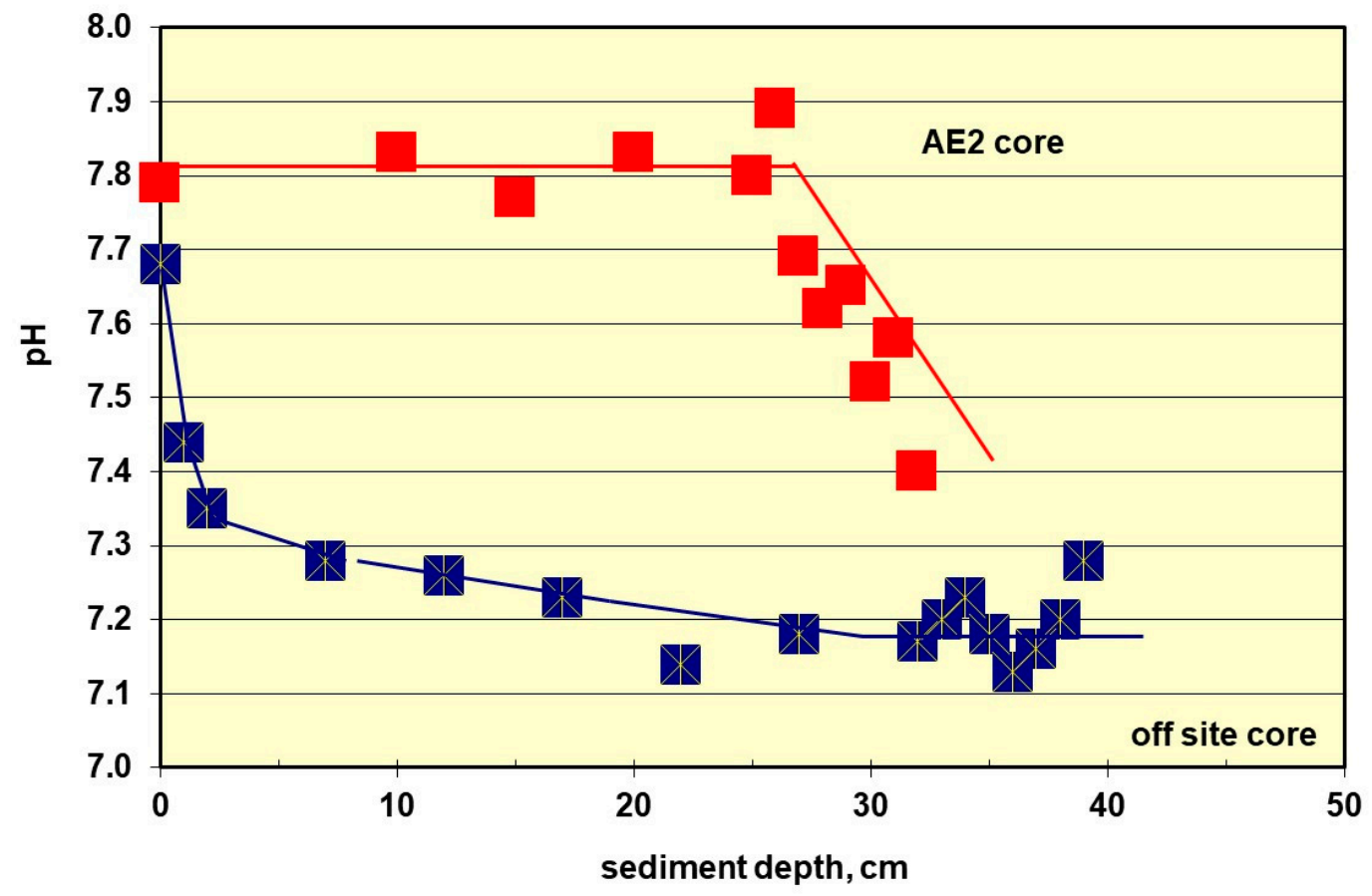

Figure 8. $\mathrm{pH}$ of AE2 core profiles and off-site values.

\subsection{Modelling Corrosion Processes on AE2}

It has been previously reported that the concretion sample was used to study how fast the corrosion reaction of steel plate equilibrates in seawater [15]. The concretion sample was attached to a section from an 1890's paddle steamer boiler, which had openable spaces to allow monitoring of both the $\mathrm{pH}$ and the chloride ions, and an insulated copper wire permitted monitoring of the $\mathrm{E}_{\mathrm{corr}}$ of the metal. During the 11-month experiment there was a systematic increase in the acidity and the chlorinity of the solutions trapped underneath the concretion. The $\mathrm{pH}$ of the seawater fell from 
7.9 to 4.3 , while the chloride increased from 16,300 to $34,600 \mathrm{ppm}$. The increased acidity was due to hydrolysis reactions of the primary corrosion product $\mathrm{FeCl}_{2}$ with water (Equation (5)).

$$
\mathrm{FeCl}_{2}+2 \mathrm{H}_{2} \mathrm{O} \rightarrow \mathrm{Fe}(\mathrm{OH})_{2}+2 \mathrm{H}^{+}+2 \mathrm{Cl}^{-}
$$

The corrosion cell took 10 months to reach equilibrium. On this basis, it is reasonable to assume that recorded in-situ values of the $\mathrm{pH}$ and the $\mathrm{E}_{\mathrm{corr}}$, of this data accurately reflect the dynamic equilibrium between the wreck and the local marine environment. Plots of the concentration of chloride and $\mathrm{pH}$ best fitted square root of time plots, which support the diffusion-controlled nature of the corrosion process. The $A E 2$ concretion corrosion cell showed that the chloride ion concentration increased by a factor of 2.1 times after sitting for 11 months in an unstirred solution. By comparison, the increase in chlorinity with the high energy surging environment of the Zuytdorp (1712) wreck, off the Western Australian coast, was 2.9 times after 270 years [3]. Monitoring of the cell $\mathrm{E}_{\text {corr }}$ value showed that it reached the on-site value in just eight months, but it took another few months of measurements to confirm that the plateau had been reached.

\subsection{Cathodic Protection System}

Given that relocation of the submarine was not a possibility, owing to the combination of the high risk of detonation of an unexpended torpedo and the prohibitively expensive creation of a dry-dock and museum conservation facility, an alternative approach to the conservation management had to be developed. In the 18th century, Volta found that the difference in reactivity of various elements could be harvested through the development of a voltaic pile, consisting of alternating layers of copper and zinc sheets. These studies were the first major experiments in differential corrosion rates of metals. The use of sacrificial reactions of a more reactive metal to provide a cathodic (negative) current, to stop the removal of electrons from a more noble metal, has been the subject of electrochemical experiments since the time of Sir Humphrey Davy, on Royal Navy copper-sheathed wooden vessels in 1761. In the case of $A E 2$, the difference in reactivity of zinc and iron provides the driving force of the cathodic protection system for the wreck. There is approximately $400 \mathrm{mV}$ difference between the $\mathrm{E}_{\text {corr }}$ of the iron on the $A E 2$ and the zinc anodes, and this is enough to stop corrosion of the submarine. As cathodic current flows through the insulated copper cables connecting the anode pods to the boat, the change of polarity causes outward migration of chloride ions and consumption of the acidity that had resulted from the accumulation of acid during the hydrolysis reactions of the corrosion products.

Design calculations considered a 5-10-year protection program and it was understood that the rate of anode consumption would be initially much higher than the long-term rate, as readily consumed hydrogen ions had built up to a moderate level underneath the concretion. Another consideration impacting on the design life was the high cost of mounting sea-borne diving operations. The final configuration consisted of three anode pods (Figure 9). The cathodic protection of the submarine is the largest in-situ conservation project ever attempted on an historic iron shipwreck. Previous work by the author has resulted in successful in-situ treatment of guns, anchors and a marine steam engine, which resulted in a more rapid processing of the artefacts from recovery to exhibition status $[2,3,16]$.

The anode pods were assembled on a $2.6 \mathrm{~m}$ sided square base, which was filled with concrete to prevent them sinking into the silt. The supporting structure weighed 0.5 tonnes, giving an aggregate weight of around 1.5 tonnes to each pod. Each anode $(150 \times 7.5 \times 7.5 \mathrm{~cm})$ had a central iron core, to which insulated current-carrying cables were attached (Figure 10). The distal end of the cable was attached to the submarine using an industrial three bolt system, as used in the cathodic protection of gas and oil production facilities. The 17 anodes on each pod had a geometric surface area of $7.84 \mathrm{~m}^{2}$. In order to achieve a good spread of protection through the length of the boat, one pod was attached aft near the rear hydroplane, one amidships at the conning tower and one up forward on the windlass (Figure 10). With an estimated geometric surface area of approximately $660 \mathrm{~m}^{2}$ for the submarine and with the area of the anodes at $23.5 \mathrm{~m}^{2}$, the industry standard ratio of approximately 30 times object to 
anode ratio was achieved. This ratio helps to avoid damage to the submarine if it was over-protected, as this could produce too much hydrogen pressure, which would blast off the protective concretion and lead to excessive consumption of anodes.

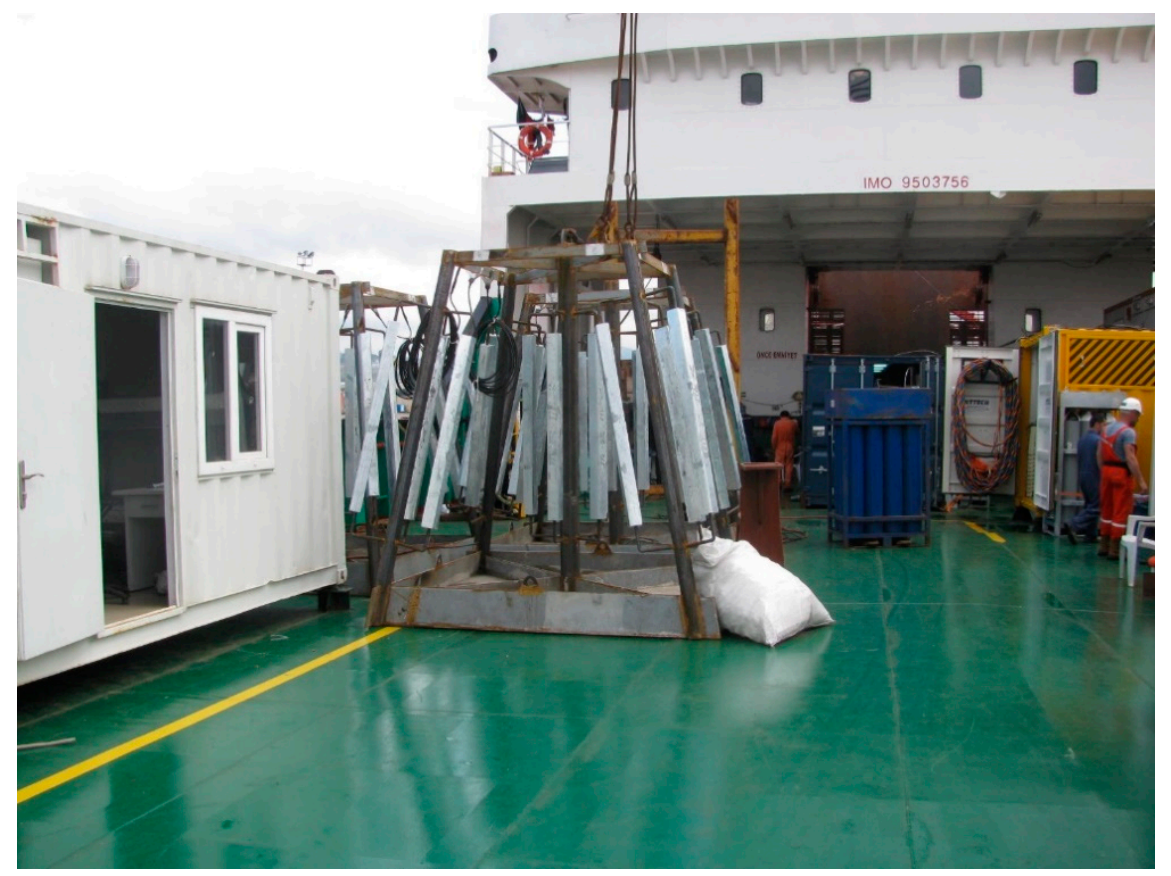

Figure 9. View of assembled anode pods prior to attachment to $A E 2$.

This ratio was developed by John McCoy of McCoy and Associates to comply with industry standards. Each of the locations was selected on the basis that there was significant residual metal present in that part of the wreck, to enable the safe and long-lasting attachment of the cables from the anode pods onto the submarine. The data listed in Table 1 reports the variability of the $\mathrm{E}_{\text {corr }}$ measurements, which were reproducible to within a few millivolts.

Table 1. Corrosion potential $\left(\mathrm{E}_{\mathrm{corr}}\right)$ measurements as a function of time (hours).

\begin{tabular}{lcccc}
\hline Date & Time & Location & $\begin{array}{c}\text { Ecorr } \\
\text { vs. Ag/AgCl }\end{array}$ & $\begin{array}{c}\text { Time, } \\
\text { hours }\end{array}$ \\
\hline 10/06/14 & $12: 45$ & $\begin{array}{c}\text { Adjacent to CT* upper hatch, } \\
\text { naturally cathodically protected }\end{array}$ & $-0.632 \pm 0.002$ & 0.1 \\
$13 / 06 / 14$ & $10: 00$ & Aft site on port, aft of the hydroplane & $-0.672 \pm 0.008$ & 96 \\
$16 / 06 / 14$ & $10: 30$ & Fwd. site, windlass shaft, 4 h later & -0.654 & 4 \\
$16 / 06 / 14$ & $14: 30$ & Fwd. site, windlass shaft, 8 h later & -0.656 & 8 \\
$18 / 06 / 14$ & $09: 15$ & Anodes attached midships to CT* & $-0.678 \pm 0.003$ & 141 \\
\hline
\end{tabular}

$\mathrm{CT}^{*}=$ Conning Tower.

Prior to attaching the anode cables with clamps to the submarine, the surfaces were hydro-blasted to remove small areas of concretion from the metal surface to get ohmic connections. The elapsed time at each attachment point was measured from the time at which the pods were attached and the time when the $\mathrm{E}_{\mathrm{corr}}$ measurements were taken. The observed voltages were dependent on the logarithm of the elapsed time between anode attachment and voltage measurement. The linear regression analysis gives Equation (6), which had an $\mathrm{R}^{2}$ of 0.9648 with an associated equation,

$$
\mathrm{E}_{\mathrm{corr}}=-0.646(0.002)-0.014(0.001) \log t_{\text {hours }}
$$


The numbers in parentheses are the errors associated with the intercept and the rate at which the submarine was being cathodically polarised. Since all the measurements fall along the same line, this indicated that the submarine was acting as an interconnected electrical unit, which was an unexpected bonus as it indicated that the overall condition of the submarine was structurally sound.

The data in Table 1 shows that the greatest voltage drop between the natural cathodic protected $\mathrm{E}_{\text {corr }}$ of the conning tower was $50 \mathrm{mV}$ after $141 \mathrm{~h}$ or close to eight days. This voltage drop is the equivalent of a $42 \%$ drop in the corrosion rate of the submarine, which is remarkable given the size of the boat! The $\mathrm{E}_{\mathrm{corr}}$ values are diagrammatically illustrated in Figure 11. This calculation is based on a combination of theoretical and practical determination of the rate at which the corrosion changes for concreted materials. For electrochemically controlled reactions, such as the in-situ treatment of the $A E 2$ submarine, the log of the corrosion rate can be calculated according to the changes in $\mathrm{E}_{\text {corr }}$ values, with a drop of approximately $330 \mathrm{mV}$ needed for a ten-fold decrease in the rate of corrosion.

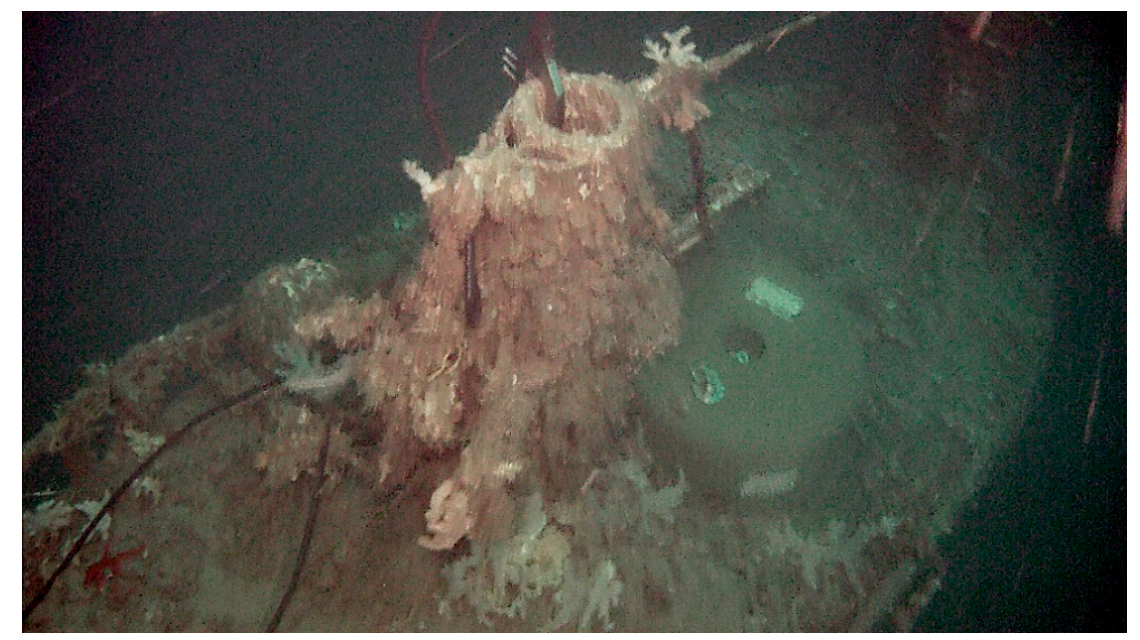

Figure 10. Clamp and cable arrangements for central anode pod connection to the conning tower. Note the replica hatch is in the "locked down" position.

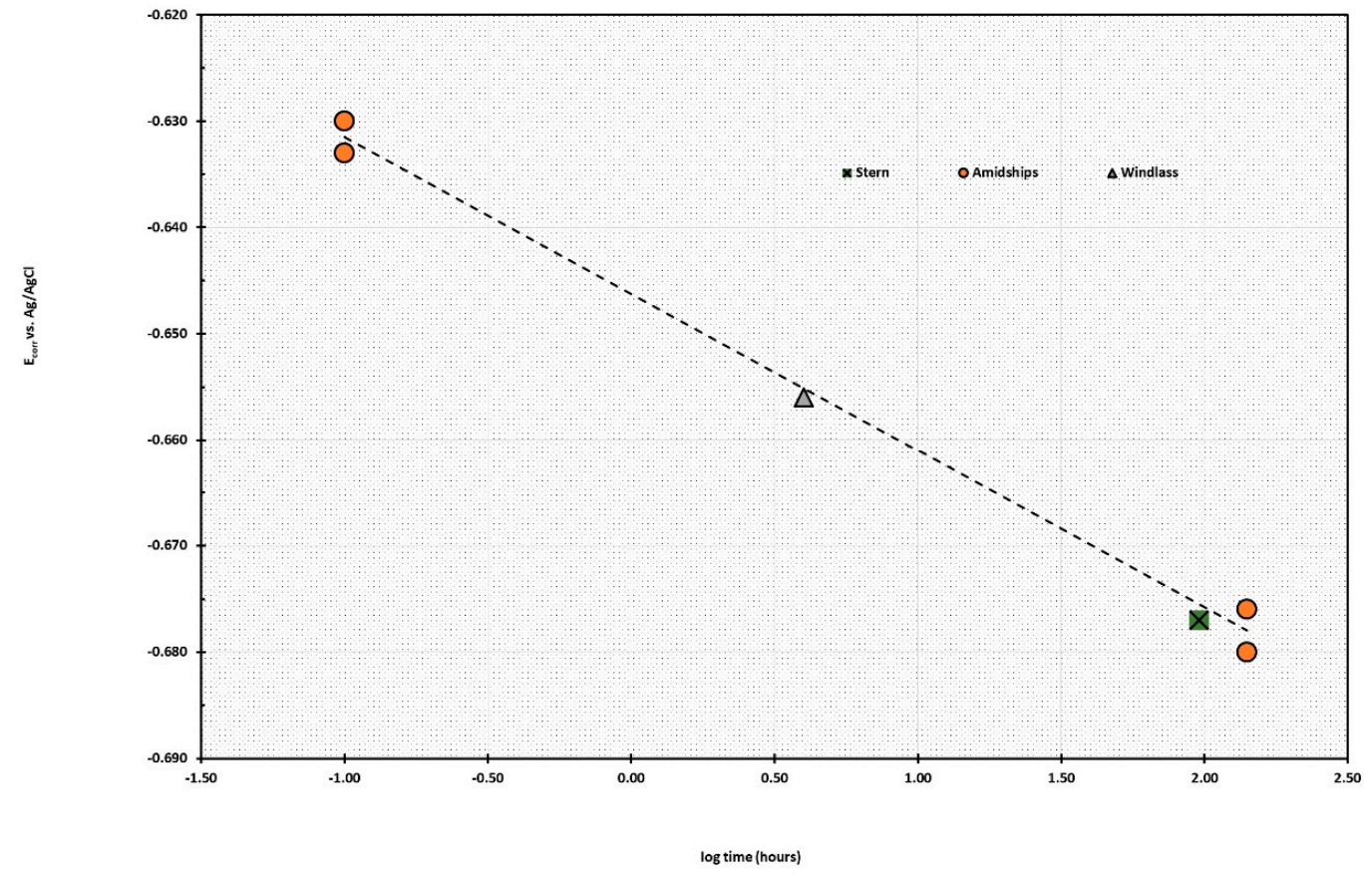

Figure 11. Plot of the $\mathrm{E}_{\mathrm{corr}}$ values vs. log time (hours) after application of anodes. 


\subsubsection{Chemical Environment in the Water Column and Inside AE2}

During diving operations on the 2014 expedition, the ROV and the attached Sonde recording the in-situ data became stuck inside the submarine for just over a day, recording information every $20 \mathrm{~s}$. A total of nearly 657,900 sets of 12 variables were recorded before the ROV was recovered, but before the data could be analysed it had to be averaged over every two minutes, as there was insufficient memory on the museum computers to resolve nearly eight million data points. One of the first outcomes of this analysis was that the apparent halocline observed in 2007, with the drop camera, was an artefact due to poor lighting and specular reflection from suspended material inside the vessel.

The $\mathrm{pH}$ data recorded by the Sonde is shown versus time inside the conning tower (Figure 12). The red-brown line shows a fall from the surface value that is within the normal range of $\mathrm{pH}$ for the Sea of Marmara, which has an average $\mathrm{pH}$ of $8.26 \pm 0.18$. The green line represents the period when the Sonde was inside the submarine and operating as normal, which shows an average $\mathrm{pH}$ of $7.15 \pm 0.03$, which is typical of marine sediments that have bacteria active in them.

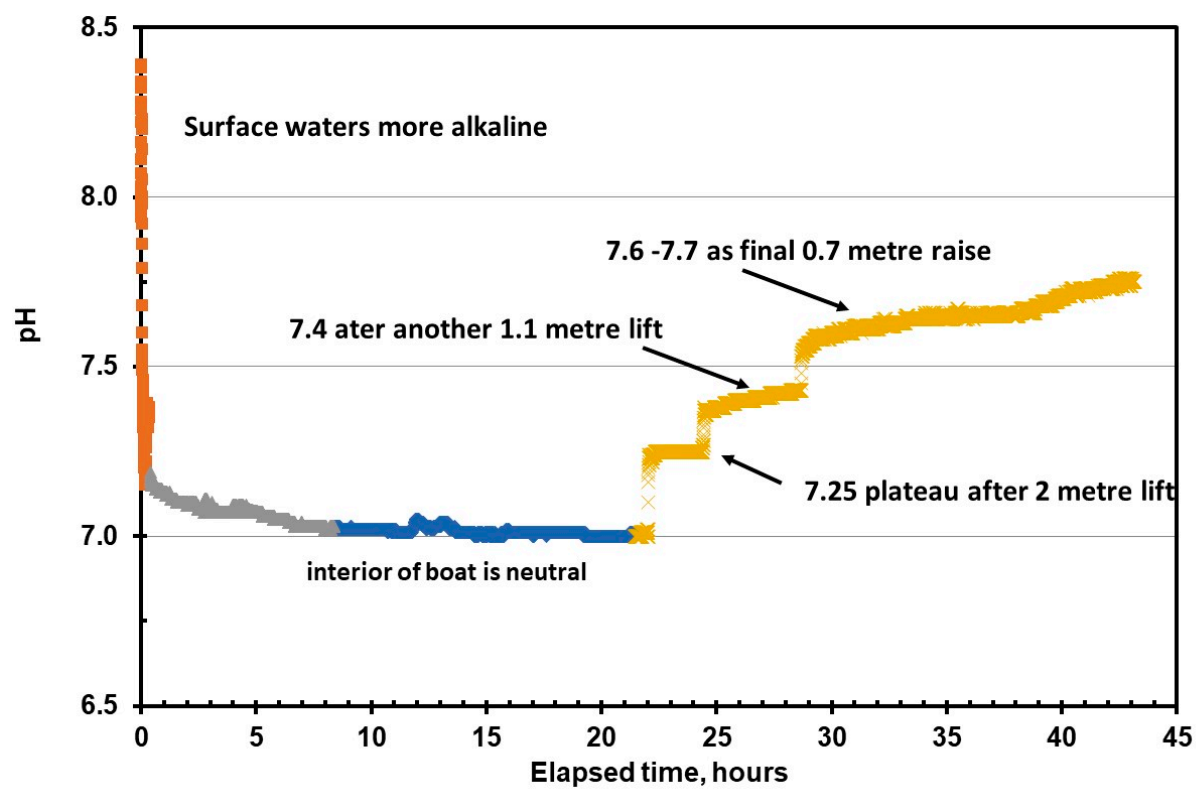

Figure 12. Plot of the $\mathrm{pH}$ of the water column and interior of the submarine.

The extended blue line represents the period when the oxygen and salinity sensors were "poisoned" by sulphur species in the stirred-up sediment. When the divers began to recover the Sonde, the purple line and the plateau value of 7.2 represents the solution value in the water column above the sediment. As the instrument recovery operations increased, the plateau readings of 7.4 and 7.6 represent the different chemical microenvironments inside the submarine. The value of 7.4 is for the water $3.1 \mathrm{~m}$ up from the floor of the control room and 7.6 is for water at $3.8 \mathrm{~m}$. The latter $\mathrm{pH}$ corresponds to the mean $\mathrm{pH}$ of the sediment cores from outside the submarine. The values between 7.2 and 7.4, those closer to the internal spaces of the lower control room, correspond with the mean $\mathrm{pH}$ $(7.26 \pm 0.08)$ from the external core adjacent to the submarine. The equivalent value at the first plateau region of the $\mathrm{pH}$ with the sediment core close to the submarine is a strong indication that the chemical processes of diagenesis inside the submarine were the same as those externally, but near the hull.

\subsubsection{Analysis of the Dissolved Oxygen profiles inside AE2}

The dissolved oxygen inside the conning tower was generally around $3.2 \pm 0.1 \mathrm{ppm}$ but there were a series of rapidly rising and falling spikes, which saw an upward excursion to approximately $4.0 \pm 0.2$ $\mathrm{ppm}$. At times these elevated levels were restored to their former values with a sigmoidal decrease in the concentration of oxygen. This is probably due to bacteria that consumed oxygen. More generally, 
there was a rapid return to the steady state value, as shown in Figure 13. These phenomena indicate that there is mixing of different bodies of water inside the conning tower and that there is a significant level of microbiological activity inside the submarine.

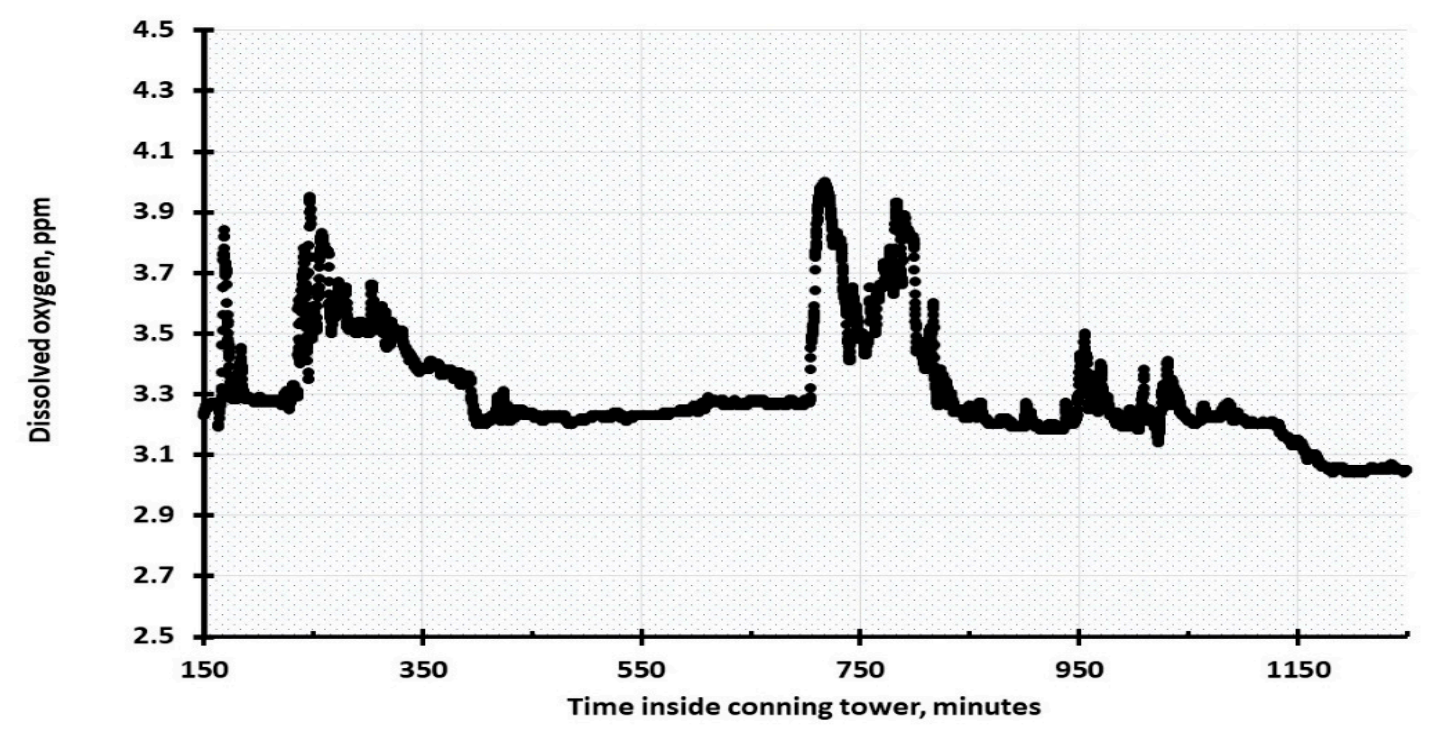

Figure 13. Plot of dissolved oxygen vs. time inside the conning tower.

The specific time intervals have no meaning other that providing an insight into the fluid dynamics inside the submarine. There was an interval between 400 and 700 min when there was no apparent mixing of the layers of solution, but the time between oxygen spikes was typically $75 \pm$ five minutes. The varying speeds at which the elevated dissolved oxygen levels resumed their stasis values were due to which of the three processes were dominant: Firstly, there is natural diffusion from a high to a low concentration of oxygen, the second is bacterial consumption, and the third method is water movement around the sensing heads of the Sonde. Imaging recovered from the ROV showed large black algal matts. The simplest explanation of the oscillating oxygen levels is that the Sonde was positioned at a point where there was movement of different bodies of water inside the submarine, and that, at times, a more oxygenated solution flowed into the boat from an external source. Inspection of the dissolved oxygen vs. depth plots, in Figure 2, show that just above the submarine the oxygen concentration was around $4 \mathrm{ppm}$, and so mixing of these waters with the internally equilibrated solutions would result in the fluctuations. Observations from the ROV operators of the cameras inside the submarine confirm that there was a small but measurable flow of water inside the control room and the waterborne sediments fall from suspension when the current meets the bulkhead. At this point the changed direction of water flow caused the sediment to collect in that area of the control room. The entrapment of the Sonde inside the submarine was extremely fortunate for it provided an extended period of passive observation of how the currents were changing the chemical environment inside the submarine. The data from the Sonde indicates that there are a range of environments inside the submarine that range from low oxygen to anaerobic, and that these different environments will have varying effects on the corrosion of artefacts that are naturally retained within the confines of the hull of $A E 2$.

\section{Conclusions}

The data gathered from in-situ corrosion measurements on the hull of the submarine AE2 and the core profiles close to and $20 \mathrm{~m}$ from the vessel has shown that the dense marine concretion and the great depth of the wreck site is providing a relatively benign storage environment for the vessel. 
The rate at which the dissolved oxygen profile fell in the two core samples indicated that the submarine corrosion is consuming oxygen from the surrounding silty sediments. Analysis of the $\mathrm{pH}$ and $\mathrm{E}_{\mathrm{corr}}$ data from the cores shows that the sample near the submarine is controlled by the reduction of oxygen in the sediments, whereas this is not the case for the core some $20 \mathrm{~m}$ distance from the submarine. It can be concluded that the submarine has a real but limited impact on the silt and sediments.

Data from the corrosion simulation experiment showed that it takes approximately one year for a concreted lump of iron to establish the long-term microenvironment that is routinely assessed when making in-situ measurements on historic shipwrecks. Not only does this data of direct measurement of chloride ion activity and the $\mathrm{pH}$ of the interstitial solution confirm the nature of the corrosion mechanism for marine iron, but it also provides opportunities to test the efficacy of changing the environment as a means of moderating the rate of decay of historic iron shipwrecks. It is possible to use such corrosion cells to directly gauge the impact of cathodic currents on the interface of the metal and the concretion. As a result of this work, the $A E 2$ is now being actively conserved while remaining in-situ at the bottom of the Sea of Marmara. Not only will this cathodic protection system stop corrosion of $A E 2$, it will actively remove chloride ions and so stabilize the vessel and preserve it for future generations.

Measurements inside the conning tower and in the operational spaces of the interior of the submarine show that bacterial consumption of fractions of the diesel fuel, and other lubricants that have escaped from storage tanks inside the boat, has significantly reduced the chemical hazards associated with leaking diesel fuel. Accidental trapping of the Sonde inside the conning tower for one day determined that the interior of the submarine is much the same as the exterior, with around 3 parts per million dissolved oxygen and a salinity of 40 parts per thousand. There appear to be breaches in the submarine that allow a small amount of external seawater to flow into the open spaces. Silt layers within the boat are like the mound on which the $A E 2$ sits, in that they are totally anaerobic, with active sulphate-reducing bacteria producing sulphide rich metabolites. Owing to the low level of dissolved oxygen inside the submarine, the corrosion implications of the "contamination" are not of major significance.

Funding: This research received no external funding.

Acknowledgments: Vicki Richards was very helpful in assembling the field equipment, the AE2 Commemorative Foundation provided logistical and financial support for the Turkish operations, Roger Neill and Peter Graham from the Defence Science and Technology Organization gave vital assistance in the field. Special thanks go to Rear Admiral (retired) Peter Briggs AO, CSC, for his inspirational leadership.

Conflicts of Interest: The author declares no conflict of interest.

\section{References}

1. Smith, T. Project Beneath Gallipoli, The underwater archaeology of the Dardanelles Battlefields. Newsl. Australas. Inst. Marit. Archaeol. 2010, 29, 4-6.

2. MacLeod, I.D. Conservation of the steam ship "Xantho". ICCM Bull. 1986, 12, 66-94. [CrossRef]

3. MacLeod, I.D. In-situ conservation of cannon and anchors on shipwreck sites. In Conservation of Archaeological Sites and Its Consequences; Roy, A., Smith, P., Eds.; IC: London, UK, 1996; pp. 111-115.

4. MacLeod, I.D. Corrosion and conservation management of iron shipwrecks in Chuuk Lagoon. Conserv. Manag. Archaeol. Sites 2006, 7, 203-223. [CrossRef]

5. MacLeod, I.D.; Beger, M.; Richards, V.; Jeffery, B.; Hengeveld, M. Dynamic interactions of marine ecosystems with wrecks in Chuuk Lagoon, Federated States of Micronesia in Metal 07. In Proceedings of the ICOM-CC Metals Working Group Meeting, Amsterdam, The Netherlands, 17-21 September 2007; Degrigny, C., Ankersmit, B., Yolanda, I., van Langh, R., Eds.; Volume 3, pp. 51-54.

6. Riley, J.P.; Skirrow, G. Chemical Oceanography, 2nd ed.; Academic Press: London, UK, 1975; Volume 1.

7. MacLeod, I.D. Formation of marine concretions on copper and its alloys. Int. J. Naut. Archaeol. Underw. Explor. 1982, 11, 267-275. [CrossRef]

8. North, N.A. Proximity corrosion in seawater. Corros. Australas. 1989, 14, 8-11. 
9. Arnold, J.B., III; Fleshman, G.M.; Hill, D.B.; Peterson, C.E.; Stewart, W.K.; Gegg, S.R.; Watts, G.P., Jr.; Weldon, C. The 1987 Expedition to the MONITOR National marine Sanctuary: Data Analysis and Final Report; Sanctuaries and Reserves Division; National Oceanic and Atmospheric Administration: Washington, DC, USA, 1991; pp. 1-70.

10. Neill, R.; (Defense Science Technology Organization, Department of Defense, Fishermans Bend, Melbourne, Australia). Personal communication, 3 June 2018.

11. North, N.A. The formation of coral concretions on marine iron. Int. J. Naut. Archaeol. Underw. Explor. 1976, 5, 253-258. [CrossRef]

12. Ozenbas, M. Consultation in Preparing a Report on Tests Made in Near Vicinity Mud and Metal of Sunk AE2 Submarine; Consultancy Report 07-03-08-01-00-23; Middle East Technical University, Department of Metallurgical and Materials Engineering: Ankara, Turkey, 2008; pp. 1-21.

13. MacLeod, I.D.; Morrison, P.; Richards, V.; West, N. Corrosion monitoring and the environmental impact of decommissioned naval vessels as artificial reefs. In Proceedings of the International Conference on Metals Conservation (Metal 2004), Canberra, Australia, 4-8 October 2004; Hallam, D., Ed.; National Museum of Australia Ashton: Canberra, Australia, 2004; pp. 53-74.

14. MacLeod, I.D.; Cook, D.; Schindelholz, E. Corrosion and conservation of the American civil war ironclad USS Monitor (1862). In Proceedings of the ICOM-CC Triennial Meeting, New Delhi, India, 22-26 September 2008; pp. 279-285.

15. MacLeod, I.D. Corrosion and Conservation Management of the HMAS AE2 (1915) Submarine in the Sea of Marmara, Turkey. In Proceedings of the Interim Meeting of the ICOM-CC Metal Working Group (METAL 2010), Charleston, SA, USA, 11-15 October 2010; Mardikian, P., Chemello, C., Watters, C., Hull, P., Eds.; Clemson University: Clemson, SC, USA, 2011; pp. 56-62.

16. MacLeod, I.D. In-situ corrosion studies on the Duart Point wreck 1994. Int. J. Naut. Archaeol. 1995, $24,53-59$. [CrossRef]

(C) 2019 by the author. Licensee MDPI, Basel, Switzerland. This article is an open access article distributed under the terms and conditions of the Creative Commons Attribution (CC BY) license (http:/ / creativecommons.org/licenses/by/4.0/). 